\title{
BRITISH POLITICS AND THE LABOUR QUESTION, 1868-1990
}




\title{
BRITISH POLITICS AND THE LABOUR QUESTION, 1868-1990
}

\author{
DAVID POWELL
}


ISBN 978-0-333-54850-9

ISBN 978-1-349-22464-7 (eBook)

DOI 10.1007/978-1-349-22464-7

(C) David Powell 1992

Softcover reprint of the hardcover 1st edition 1992

All rights reserved. For information, write:

Scholarly and Reference Division,

St. Martin's Press, Inc., 175 Fifth Avenue,

New York, N.Y. 10010

First published in the United States of America in 1992

ISBN 978-0-312-08374-8

Library of Congress Cataloging-in-Publication Data

Powell, David.

British politics and the labour question 1868-1990 / David Powell.

p. $\mathrm{cm}$.

Includes bibliographical references and index.

ISBN 978-0-312-08374-8

1. Labor movement-Great Britain-History. 2. Labor policy-Great

Britain-History. 3. Industrial relations-Great Britain-History.

4. Great Britain-Politics and government-19th century. 5. Great

Britain-Politics and government-20th century. I. Title.

HD8390 . P79 1992

$322^{\prime} .2^{\prime} 0941-\mathrm{dc} 20$

92-18697

CIP 


\section{Contents}

Preface

Introduction: Politics and the Labour Question

1 The Emergence of the Labour Question, 1868-1906

2 The Liberal Ministries and Labour, 1906-15

3 The Labour Question in War and Peace, 1915-26

4 Depression and Integration, 1926-45

5 British Politics and the Labour Question since 1945

Conclusion

Appendix 1: Chronology

Appendix 2: Trade Union Membership and the Labour Vote

Notes

Further Reading

Index 


\section{PREFACE}

Twice in the 1970s - in February 1974 and May 1979 - British governments suffered electoral defeat in part at least because of their failure to maintain good relations with the trade unions and to prevent the spread of industrial unrest. Mrs Thatcher's government took office in 1979 pledged to curb the power of the unions once and for all. The erosion of union strength was to be one of the main legacies of the Thatcher years. Yet the events of the 1980s can properly be assessed only in a longer perspective. The 'Labour question' with which recent governments have had to deal was not the product of the 1970s, nor even of the period since 1945. It had its roots in the previous century and has been a constant factor in the calculations of governments from the days of Gladstone onwards. The purpose of this book is therefore to trace the emergence and analyse the nature of the Labour question as it has developed since the mid-nineteenth century and to assess its impact on British politics in that time. What follows is not intended either as a narrative history of the Labour party or an institutional study of trade unionism. The focus is rather on the relationship between the Labour movement and wider processes of political change, in particular the effect of Labour's rise on the structure of the party system, the conduct of industrial relations and the attitudes of government to questions of industrial reform and trade union law. In this way it is hoped to complement rather than duplicate the many excellent surveys of Labour politics which have already been written and to provide a brief yet coherent account of what is 
undoubtedly one of the most important strands in the political history of modern Britain.

In writing a study of this kind I have naturally had to draw on the or:ginal work of numerous other historians, and I can only express my thanks to those scholars whose ideas and research I have so shamelessly plundered. I am grateful to the editor of the series, Jeremy Black, and to the publishers for showing faith in the project at an early stage. My deepest debt of gratitude is to my wife, Pyrrha, for putting up with so much for so long. 